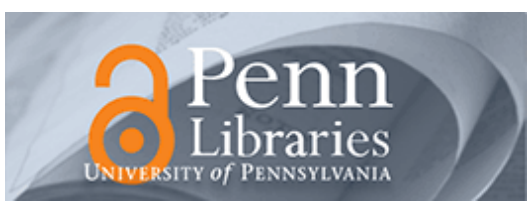

University of Pennsylvania ScholarlyCommons

1992

\title{
Dialogue of Genres in Ovid's "Lovesong of Polyphemus" (Metamorphoses 13.719-897)
}

Joseph Farrell

University of Pennsylvania, jfarrell@sas.upenn.edu

Follow this and additional works at: http://repository.upenn.edu/classics_papers

Part of the Classics Commons

\section{Recommended Citation}

Farrell, J. (1992). Dialogue of Genres in Ovid's "Lovesong of Polyphemus" (Metamorphoses 13.719-897). The American Journal of Philology, 113 (2), 235-268. http://dx.doi.org/10.2307/295559 


\title{
Dialogue of Genres in Ovid's "Lovesong of Polyphemus" (Metamorphoses
} 13.719-897)

\begin{abstract}
Among the central critical issues surrounding Ovid's Metamorphoses--indeed, underlying many of this challenging text's unsolved problems--is the question of genre. Is the poem epic or a species of epic (e.g., antiepic, epic parody, elegized epic, or epicized elegy); a type of Kollektivgedicht, stringing together either a series of examples from some miniature form such as the epyllion, or else sampling now one genre, now another; or is it simply unique, resisting any effort at categorization? Despite the intelligent and detailed discussion that the question has received during the past seventy-five years, it is safe to say that no critical consensus has emerged.
\end{abstract}

\section{Disciplines}

Arts and Humanities | Classics 


\section{DIALOGUE OF GENRES IN OVID'S "LOVESONG OF POLYPHEMUS" (METAMORPHOSES 13.719-897)}

Among the central critical issues surrounding Ovid's Metamorphoses-indeed, underlying many of this challenging text's unsolved problems-is the question of genre. Is the poem epic or a species of epic (e.g., anti-epic, epic parody, elegized epic, or epicized elegy) ${ }^{1}$ a type of Kollektivgedicht, stringing together either a series of examples from some miniature form such as the epyllion, ${ }^{2}$ or else sampling now one genre, now another; ${ }^{3}$ or is it simply unique, resisting any effort at categorization ${ }^{4}$ Despite the intelligent and detailed discussion that the

${ }^{1}$ The considerable literature on the Metamorphoses and the epic genre is conveniently reviewed by Stephen Hinds, The Metamorphosis of Persephone. Ovid and the self-conscious Muse, Cambridge Classical Studies (Cambridge 1987) 99-114.

${ }^{2}$ Edgar Martini, "Ovid und seine Bedeutung für die römische Poesie," in Epitymbion Heinrich Swoboda dargebracht, ed. M. San Nicolo (Reichenberg 1927) 167-68; M. Marjorie Crump, The Epyllion from Theocritus to Ovid (Oxford 1931) 203-4; Brooks Otis, "Ovid and the Augustans," TAPA 69 (1938) 189; Douglas Little, "Richard Heinze: Ovids elegische Erzählung," in Ovids Ars amatoria und Remedia amoris. Untersuchungen zum Aufbau, ed. Ernst Zinn (Stuttgart 1970) 72.

3 Joseph Solodow, The World of Ovid's Metamorphoses (Chapel Hill and London 1988) 17-18, invokes the notion that "the poem is comprehensive in chronology, in subject matter, and in literary genres," and goes on to note that, though the poem's comprehensiveness is "less seldom observed" in the matter of incorporating various literary genres than in other respects, nevertheless "at one place or other it handles the themes and employs the tone of virtually every species of literature."

${ }^{4}$ Thus Michael von Albrecht, while acknowledging the epic orientation of the poem, calls the Metamorphoses “. . . ein Epos sui generis, und in diesem Zusatz liegt das Entscheidende" (P. Ovidius Naso. Metamorphosen, ${ }^{10}$ erklärt von M. Haupt-R. EhwaldM. von Albrecht [Berlin 1966] erster Band, 486). G. Karl Galinsky (Ovid's Metamorphoses. An Introduction to the Basic Aspects [Berkeley and London 1975] 41) goes farther: ". . . it would be misguided to pin the label of any genre on the Metamorphoses." It is also argued that the concept of genre was of minor importance in the Augustan age: see, for instance, David O. Ross, Jr., Backgrounds to Augustan Poetry. Gallus, Elegy, and Rome (Cambridge 1975) 37: “The discovery [i.e., in Vergil's Sixth Eclogue] of a single unified tradition comprehending a variety of forms and genres means that genre need no longer count for much." Cf. Peter E. Knox, Ovid's Metamorphoses and the Traditions of Augustan Poetry, Cambridge Philological Society Supplementary Volume no. 11 (Cambridge 1986) 1: "The rules of genre count, but only so that the reader may recognize when they are broken." 
question has received during the past seventy-five years, it is safe to say that no critical consensus has emerged.

What the most stimulating approaches to the question have tended to share is adherence in some form to Wilhelm Kroll's concept of Kreuzung der Gattungen, the process typical of most Hellenistic and Roman poetry by which traditional generic categories are revived and refreshed through creative analysis and recombination. ${ }^{5}$ The Metamorphoses, however we conceive of its generic status, clearly owes a great deal to this principle. And yet, Kroll's formulation has been useful only to a point. Part of the reason for this may be the limited way in which Kroll described the principle and handed it on to later scholars. For most, the idea of Kreuzung involves a kind of patchwork approach, in which discrete generic elements-elements, let us say, of tragedy or comedy-retain their distinct generic identity in juxtaposition with elements of other genres, such as elegy or epic, or even when subsumed within a predominantly elegiac or epic context. ${ }^{6}$ Such an approach of course can be and indeed has been applied to the Metamorphoses, with useful results. Formally, the poem is epic because of its length and because it is written in the epic meter; and yet many individual passages vary the conventions of epic with those of other genres. Thus, for example, the warrior god Apollo is made to act like the frustrated lover of comedy and elegy, ${ }^{7}$ while Venus, the goddess of love, speaks the epic language of grand strategy and universal empire. ${ }^{8}$ But so many scholars have found the epic label unacceptable that to privilege two formal characteristics, length and meter, over all other generic considerations now seems arbitrary. ${ }^{9}$ Even for the ancients these factors were not utterly decisive, ${ }^{10}$ and by any other measure, we cannot comfortably

${ }^{5}$ Studien zum Verständnis der Römischen Literatur (Stuttgart 1924) 202-24.

${ }^{6}$ Examples run from the very limited, such as the inclusion of epigrammatic verses in longer poems (e.g., Vergil, Aeneid 3.288; Tibullus 1.3.55-56, 1.9.83-84, [3.2.29-30]; Propertius 2.13.35-36, 2.14.27-28, 4.3.72, 4.7.85-86), to the much more ambitious, such as the "Aristaeus" epyllion that concludes Georgics 4.

${ }^{7}$ Warrior: Met. 1.454-62; lover: 1.490-524.

${ }^{8}$ Hinds (note 1 above) 108-9, 133-34, 167, nn. 44, 45, 2.

${ }^{9}$ For instance, Little (note 2 above) 71, criticizing Heinze's assumption that the poem's form makes it an epic, notes that "Heinze makes no mention of unity of theme, of consistency of purpose, of what L. P. Wilkinson calls 'the end in view,' which, to my mind, is a sine qua non of epic."

${ }^{10}$ Aristotle, for instance, denied that Parmenides and Empedocles were poets at all (Poetics 1.11), and regarded Homer as the supreme poet not only of epic, but of both 
situate the poem in the epic canon alongside the Iliad and the Aeneid. This judgment reflects not on the quality of the Metamorphoses, but on its manifold departures from the epic norm which the Iliad and the Aeneid much more nearly represent. These departures are expressed most frequently in terms of diction, themes, forms of behavior, and other elements that traditionally defined a wide variety of genres. Furthermore, many of these elements cannot be isolated within limited portions of the text. The style employed throughout the entire poem is generically diverse, drawing deeply upon the conventions of genres other than epic, particularly elegy, ${ }^{11}$ while many of the stories, regardless of their other generic associations, are set in a conventional pastoral landscape. ${ }^{12}$ The problem, then, is to make sense of the prolific play of generic elements that characterizes the Metamorphoses as a whole, and to do so in a way that does not prejudice the matter by regarding any one genre as primary.

One can easily conceive of a more organic approach to genre, one that would take the biological metaphor of Kreuzung more seriously. Thus the "crossing" of two or more genres would be seen to produce a tertium quid, generically (and "genetically") descended from each of the parent genres and bearing hereditary features of each, but no longer subject to traditional classification. This alternative conception of $\mathrm{Kreu}$ zung, with its stress on the newness of the generic hybrid, would in my view have provided the more promising line of approach. By now, however, the metaphor of Kreuzung has become so encumbered by the

tragedy and comedy as well (4.12). On the various ancient definitions of epic see Severin Koster, Antike Epostheorien, Palingenesia 5 (Wiesbaden 1970). It may be of interest, as the editor reminds me, that Quintilian does not mention Ovid in his survey of Roman epic poets at $I O 10.1 .85-92$.

${ }^{\prime \prime}$ E. J. Kenney ("The Style of the Metamorphoses, in Ovid, ed. J. W. Binns [London and Boston 1973] 126) speaks of the poem's diction as "extending . . the poetical koine that in his amatory works he had already gone a long way towards establishing as what might be called the standard literary dialect of Latin." Knox (note 4 above) goes farther in tracing many of Ovid's departures from conventional epic language to the influence of elegy. See also Hermann Tränkle, "Elegisches in Ovids 'Metamorphosen,", Hermes 91.1963.459-76.

${ }^{12}$ Hugh Parry, "Ovid's Metamorphoses: Violence in a Pastoral Landscape," TAPA 95 (1964) 268-82. Charles Paul Segal, Landscape in Ovid's Metamorphoses: A Study in the Transformations of a Literary Symbol, Hermes Einzelschriften, Heft 23 (Wiesbaden 1969); J. Danielewicz, "Some Observations on the Technique and Contextual Role of the Scenery Descriptions in Ovid's 'Metamorphoses', Eos 59 (1971) 301-7. 
weight of traditional interpretation that an attempt to redeploy it seems futile. In addition, any such approach will be strictly limited to generic considerations, and will be capable of providing little or no access to larger interpretive concerns. Thus the notion of the poem as something new rather than as the imperfect representative of a class is both liberating and necessary. But what is needed is a new critical model, one that builds upon this notion and is also capable of relating questions about the general character of the Metamorphoses to broader critical issues.

For these reasons, the relationship among the constituent genres of Ovid's poem is best conceived in terms of dialogue. ${ }^{13}$ By this I mean that we should not think of a primary generic background-e.g., of epic - varied by occasional applications of elegiac, comic, or other elements. Rather, all of the constituent genres represent different "voices" or even "languages" present in a state of constant interaction throughout the poem. Its genre can therefore not be identified with any of these voices or languages individually. Instead, it is characterized chiefly by this very element of polyphony, of openness to the influence of different genres, stylistic registers, and ideologies. This is a characteristic which the poem shares with many other, formally divergent works representing many cultures and times. Dante's Divina Commedia, particularly Inferno, embraces not only epic and romance, but the most solemn and sublime devotional utterances together with viciously scatological invective. Similarly, Joyce's Ulysses obviously exploits the conventions not only of various novelistic traditions, but of the epic, Platonic dialogue, and a wide variety of unconventional forms ranging from the Roman Catholic Mass and catechism to limerick and doggerel verse. Nor is the impulse to dialogism confined to such monumental works as these. In ancient times, satire was always and practically by definition a polyphonic genre, and the verse epistles of Horace and Ovid could be

${ }^{13}$ In what follows I have been greatly influenced by M. M. Bakhtin, The Dialogic Imagination, ed. Michael Holquist, trr. Caryl Emerson and Michael Holquist, University of Texas Press Slavic Series, no. 1 (Austin 1981). A number of Bakhtin's untranslated essays on the subject are discussed by Tzvetan Todorov, Mikhail Bakhtin. The Dialogical Principle, tr. Wlad Godzich, Theory and History of Literature, Volume 13 (Minneapolis 1984). See also Michael Holquist, Dialogism: Bakhtin and his World (London-New York 1990). Bakhtin is also my immediate source for the concept of literary "polyphony," to which I appeal later in this paper. 
profitably studied from this perspective. ${ }^{14} \mathrm{~A}$ good modern representative would be Saul Bellow, whose characters speak a variety of hybrid languages, which derive from the most disparate individual dialects, and live in a correspondingly disjointed and heterogeneous world. ${ }^{15}$

When the matter is stated in these terms, it becomes clear that the Metamorphoses is not sui generis, a genre of one; also that we have begun to speak of a genre that, unlike those that we have mentioned previously, cannot be defined in purely formal terms-or, for that matter, adequately labeled. ${ }^{16}$ This unnamed genre presents the reader, not

${ }^{14}$ Bakhtin himself has traced the literary origins of dialogism to the "serio-comical genres," among which he includes Plato's Socratic texts, Xenophon's Cyropaedia, Menippean satire, and Petronius' Satyrica (Bakhtin, 1981 [note 13 above] 21-22). Ancient material however remained no more than the background for his work on later texts, particularly in Rabelais and his World, tr. Helene Iswolsky (Cambridge, MA 1968) and Problems of Dostoyevsky's Poetics, tr. and ed. Caryl Emerson (Minneapolis 1984).

${ }^{15} \mathrm{~A}$ particularly clear example of both the linguistic and social amalgam that is Bellow's world is provided by an exchange between the free-lance intellectual Charlie Citrine and the small-time gangster Rinaldo Cantabile in Humboldt's Gift (New York 1975). Cantibile has been terrorizing Citrine for stopping payment on a check written to cover a $\$ 450.00$ loss in a poker game, eventually offering to call off the harrassment if Citrine will agree to provide his wife, a doctoral candidate in American literature, with personal information for her thesis on Citrine's friend, the writer Von Humboldt Fleischer. After listening with irritation to the proposal, Citrine replies, "The $\mathrm{Ph}$.D. racket is a very fine racket, but I want no part of it" (p. 106).

${ }^{16}$ For Bakhtin this genre is the novel, a category which he takes to include not only Don Quixote and The Brothers Karamazov, but also the dramas of Henrik Ibsen and Gerhart Hauptmann, the epic poetry of Byron (Childe Harold's Pilgrimage and Don Juan), and the lyrics of Heinrich Heine (Bakhtin, 1981 [note 13 above] 5-6). While I take the point, to avoid needless confusion I do not adopt the term "novel" to denote the genre that we are discussing. Note also that Bakhtin's definition of this genre in contrast to the traditional formal genres, particularly Greco-Roman epic, needs drastic revision in the light of recent criticism; the work of James M. Redfield (Nature and Culture in the Iliad: The Tragedy of Hector [Chicago 1975]) and Gregory Nagy (The Best of the Achaeans. Concepts of the Hero in Archaic Greek Poetry [Baltimore and London 1979]) on the Iliad; the recent work of John Peradotto on the Odyssey (Man in the Middle Voice. Name and Narration in the Odyssey [Princeton 1990]); and the whole approach to the Aeneid ushered in by Adam Parry ("The Two Voices of Virgil's Aeneid," Arion 2 [1963] 66-80) and Michael C. J. Putnam (The Poetry of the Aeneid: Four Studies in Imaginative Unity and Design [Cambridge 1965]) in effect reveal those poems as consummately "novelistic" in Bakhtinian terms. On this topic see Carol Olivia Herron, "The Vacillating Epic: The Dialectic of Opposing World Views in the Expansion of the Epic Literary Genre" (Diss. Pennsylvania 1985); Frederick T. Griffith and Stanley J. Rabinowitz, Novel Epics: Gogol, Dostoevsky, and National Narrative (Evanston, IL 1990). The best term currently avail- 
with the clearly reflected image of a homogeneous world, but with a refracted array of broken images that more truly depicts the divided unity of a world dominated by flux. This it could do only by fostering the simultaneous play of contrasting voices against one another, finding greater advantage in dissonance than in harmony.

These points are valid for the Metamorphoses as a whole, but their critical utility becomes clear only through detailed analysis of specific passages. The story of Acis, Galatea, and Polyphemus provides fruitful ground for such analysis. Because it is a crossroads of several distinct poetic traditions - primarily, the genres of pastoral, erotic elegy, and heroic epos - the episode clearly confronts the reader with a variety of divergent, even antithetical generic motifs which nevertheless stand in unity as its own constitutive elements. In what follows, I shall attempt to illustrate the dialogic basis of the episode's generic character by first identifying and then analyzing its main elements. By way of conclusion, I will indicate briefly how our study of this episode can inform a broader interpretation of the poem as a whole.

\section{ELEMENTS OF DIALOGISM}

The generic diversity of the Polyphemus episode manifests itself in three basic ways. First, and most obviously, Ovid adroitly combines the loci communes of three different genres. Polyphemus tends sheep (821-30 et passim), carries a staff (782), plays a Pan pipe (784), and sings pastoria sibila (785), while Acis and Galatea recline in a sheltered cave listening to his song, just like conventional figures of the pastoral genre. At the same time, the Cyclops burns with love (763, 867-69), frets over his appearance (764-67), is forgetful of his usual pursuits $(763,767-69$, 781 ), and chafes at his rival's success (859-61), like the typical elegiac lover. ${ }^{17}$ Finally, Polyphemus' size and strength (842-44, 863-64, 882$84)$, his ferocious appearance $(765-67,844-47)$, and his bloodthirsty

\footnotetext{
able to denote the genre that works like the Metamorphoses exemplify is "threshold genre" as defined by Gary Saul Morson, The Boundaries of Genre. Dostoevsky's Diary of $a$ Writer and the Traditions of Literary Utopia (Evanston, IL 1981) 39-68. Morson's book is one of the best studies of genre that I know. Note that he also speaks of "inter-generic dialogue" (pp. 79, 81-84) in a sense very close to the one I intend to outline here.

${ }^{17} \mathrm{See}$ also the useful observations of Knox (note 4 above) 34-35. These erotic elements are of course also present in Ovid's chief formal model for this episode, Theocritus' eleventh Idyll, a point to which I shall return.
} 
savagery (759-61, 768-69, 865-66, etc.), traits which cast him as an epic figure, are emphasized repeatedly. By the same token, he kills Acis in epic fashion, heaving an enormous boulder at his opponent in "single combat" (882-84), while Acis, facing his murderous onslaught, is pointedly a hero (Symaethius heros 879). The combination of these generically divergent elements in a single episode, then, is our first and most apparent indication of its dialogic nature.

Our second signpost involves the poet's art of imitation. Throughout the episode, Ovid allusively evokes the literary past in subtly specific ways, drawing upon and reacting to particular models that represent the parent genres of his composition. This technique may be viewed as a special case of the first. For instance, the pastoral setting and the structure of Polyphemus' rustic serenade clearly derive primarily from Theocritus' eleventh Idyll. But the Cyclops' sudden interest in his appearance (764-67) alludes directly to advice that Ovid himself had given in Ars amatoria. ${ }^{18}$ Similarly, the manner in which Polyphemus murders Acis - by hurling the peak of a mountain at him-is not merely conventional epic behavior, but specifically recalls the Homeric $\mathrm{Cy}$ clops' attempt to avenge himself on "Noman"/Odysseus. ${ }^{19}$ In each of these cases, Ovid alludes not to the pastoral, elegiac, or epic tradition as a whole, but to highly individual expressions of those traditions, expressions that often possess generic ambivalences of their own, as we shall see.

Our third indicator-itself in turn a special instance of the second-is the ambivalent relationship of the Ovidian episode to its chief formal model, Theocritus' eleventh Idyll, from two particular points of view. Apart from the obvious structural relationship and many borrowed motifs, the Ovidian episode also exploits the generic sophistication of its model. At the same time, it develops a very different generic character from that of the idyll; and the difference is reflected most clearly in Ovid's revision of Theocritus' narrative structure.

In negotiating the generic complexities of his Polyphemus episode, Ovid was greatly abetted by his choice of model. It is obvious that Idyll 11 is no straightforward example of pastoral poetry. Indeed, this poem is itself an authentic tour de force in respect to the play of generic categories. Having worked to establish the pastoral as a distinct subgenre of epic in the bucolic mode, contrasting with but also imitating

${ }^{18} 1.518$ sit coma, sit scita barba resecta manu. On this point see further below. ${ }^{19} \mathrm{Cf}$. Odyssey $9.481-566$. 
the heroic mode, ${ }^{20}$ Theocritus in this idyll effects a humorous confrontation between his creation and its model by introducing a consummately Homeric character into his newly created poetic world. The choice of Polyphemus for this role, though it seems almost inevitable in retrospect, was inspired. Homer's Polyphemus is a shepherd and he lives on Sicily, the home of Theocritus' herdsmen in other poems. ${ }^{21}$ Both factors suggest and facilitate the introduction of such a figure into the world of the Idylls. Moreover, the poet goes to great lengths to make Polyphemus superficially at home in the pastoral world; but inevitably the character's literary past clings to him like karma from another life, and the poet slyly encourages the reader to remember this past by subtle allusion to the Odyssey. ${ }^{22}$ The result is a humorous incongruity between the poem's implicit assumption that a creature like Polyphemus might be at home in this context and the reader's awareness that the Cyclops belongs to a different world entirely. Thus Idyll 11 is not simply an inert model on which Ovid has imperiously worked his imitative will. Rather, the poem serves as an active guide to the possibilities of generic sophistication that unfold themselves to the dialogic imagination.

Despite the importance of Theocritus' example, however, we must beware of confusing Ovid's goals with those of his great predecessor. In the pastoral idylls, Theocritus worked to construct and codify a new formal genre, based chiefly on epic, that would be reproducible by others. Idyll 11 is the most visible sign of his triumph, demonstrating a confident mastery even of material that would seem essentially incompatible with his pastoral program. By contrast, Ovid's imitation involves a strictly provisional arrangement of formal generic elements and does not seek to define a new, reproducible genre. Rather, it participates in a genre defined not, like pastoral, in formal terms, but precisely by the provisional arrangement of discordant formal elements by dialogic processes.

This difference is reflected in Ovid's alteration of the basic narrative elements found in Theocritus. It is of course a given in both poems

${ }^{20}$ See the persuasive analysis of David M. Halperin, Before Pastoral. Theocritus and the Tradition of Ancient Bucolic Poetry (New Haven 1983).

${ }^{21}$ E.g., of Thyrsis at $I d$. 1.65, of Daphnis at 1.117-21.

${ }^{22}$ André Kurz, Le Corpus Theocriteum et Homère: un problème d'authenticité (Idylle 25), Publications Universitaires Européenes, Série XV: philologie et littérature classiques, vol. 21 (Berne-Francfort/M. 1982) 135-40. 
that the beautiful Galatea will want nothing to do with the brutish Cyclops. But beyond this fact, the circumstances of his futile suit differ in the two versions. In Idyll 11, the union that Polyphemus proposes is impossible for one fundamental reason: Polyphemus is a creature of the land, while Galatea's home is in the sea. The monster himself, in suggesting ways of overcoming this difficulty, actually stresses the impossibility of his desires $(43,49,54-55,60-62,79)$. In Ovid, this motif is virtually non-existent. ${ }^{23}$ Here Galatea tells us that she finds Polyphemus' attentions unwelcome because she is enamored of another, the beautiful Acis; ${ }^{24}$ and this Acis is a formidable rival. He is a very specific anti-type of Ovid's Polyphemus. By way of outlining the situation, Galatea notes that her love for the one was equal to her hatred of the other (756-58). Whereas Acis is pulcher (753), Polyphemus is normally neglectful of his appearance (as Galatea implies in 764), is possessed of a wild look (feros . . . vultus 767; cf. ferus 780, 873), and is altogether frightening (terribilem 772). Acis is sixteen years old and just beginning to show his first beard (753-54). We do not know how old this Polyphemus is; but he grooms himself for courtship by mowing his bushy beard with a pruning hook (766), and when he admits that his entire body is covered by bristles, he argues unconvincingly that his shaggy form and full beard epitomize masculine beauty (844-50). Ironically, Acis is in this respect not only unlike Ovid's Polyphemus, but like the Polyphemus of Theocritus, who is also described as just getting his first

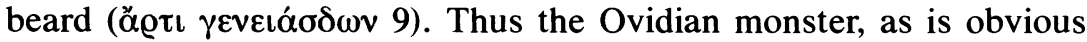
from the passages cited above, contrasts with the Theocritean one in this respect.

This contrast is only part of a larger pattern. The Theocritean monster is a creature borrowed from heroic epos and made to seem, superficially at least, at home in a pastoral setting. It is the tension between the monster's literary provenance and his amorous behavior in a pastoral setting that animate the idyll; yet the success of the poem is that this tension is, in a sense, resolved. Polyphemus' Homeric back-

${ }^{23}$ His Polyphemus once asks Galatea to leave her watery home (838-39). In Theocritus the request is made twice and at greater length $(42-49,63-66)$, with emphasis absent from Ovid's version on the contrast between land and sea.

${ }^{24}$ While Acis becomes a standard element in the story after Ovid, he is not found in earlier versions. For a survey of theories concerning a possible source see Franz Bömer, P. Ovidius Naso. Metamorphosen, Buch 13-14, Wissenschaftliche Kommentare zu lateinischen und griechischen Schriftstellern (Heidelberg 1982) 410. 
ground is not allowed to overwhelm the new role in which Theocritus has cast him. Indeed, it is a measure of Theocritus' success in creating the pastoral genre out of epic elements that he can bring off this confrontation with such aplomb. But in Ovid's narrative, Polyphemus' relationship to the pastoral setting receives a much different treatment. At no point is he really convincing as a denizen of the pastoral world. The pastoral/elegiac paradigm against which he is measured and found wanting is provided by the love of Acis and Galatea. Both characters are young and beautiful; Acis is the son of a faun and a nymph. The lovers pass their time hidden in a cave, wrapped in each other's arms, listening to Polyphemus' song. By virtue of these factors, they possess an ideal erotic relationship to one another and are endowed with a generically conventional relationship to their pastoral surroundings as well. ${ }^{25}$ Galatea, as one of these pastoral lovers, thus speaks with some authority when she depicts a Polyphemus who is credible neither as a lover nor as a creature of the pastoral world.

Not only Acis, but any hint of a rival is absent from Theocritus. In Ovid, however, the existence of a third party is essential. ${ }^{26}$ The story ends, after all, not with Polyphemus' philosophical resignation, as in Theocritus, but with the murder of Acis. Similarly, Theocritus gives Galatea no voice: she is merely the distant object of Polyphemus' fantasy. In Ovid, however, Galatea actually narrates her own story, a point to which we shall return. Theocritus successfully resolves the confrontation between his new generic creation and its epic source by representing Polyphemus in a pastoral mode, and relieves the lovesick monster's frustration by the power of song. Ovid highlights the dichotomy between, on the one hand, Polyphemus' amorous desires and bucolic surroundings, and, on the other, his violent nature, not only maintaining the Cyclops' frustration throughout the episode, but even causing him to destroy the happiness of the more convincing pastoral/elegiac lovers, Acis and Galatea.

${ }^{25}$ This point is made by Segal (note 12 above) 59.

${ }^{26}$ Vergil's imitation of Idyll 11 in Eclogue 2 does feature a rival named Iollas (57), and the fact that the protagonist of the poem, Corydon, is involved in a desperate love triangle is announced in the opening lines. Ovid's introduction of Acis into the story of Polyphemus and Galatea may have been influenced in some degree by this feature of Eclogue 2, which Ovid imitates elsewhere in this episode (as we shall see). Alternatively, the presence of a rival in Vergil's poem, but not in its model, may indicate that Vergil knew versions of Theocritus' story in which a rival, Acis, did figure. His Iollas will then have been a learned allusion to a tradition not followed by his main source. 
These differences in narrative structure reflect the seriousness of Ovid's generic dialogue. Of course Ovid, like Theocritus, achieves a number of outstandingly humorous effects by combining elements drawn from incompatible genres. But, as so often in the Metamorphoses, this humor is tempered by the troubling events that the narrative depicts. ${ }^{27}$ In the present episode, this too is related to the dialogic relationships embodied in allusion, modulation of style, and, especially, in the way in which we encounter the figure of Polyphemus. The episode thus discloses a thematic character that is typical of the Metamorphoses, but which does not fit comfortably into any of its constituent genres.

It is this narrative structure that most fully embodies the polyphonic element in Ovid's generic creativity; but the same principle informs his manipulation of generic commonplaces and his allusive artistry as well. It is not sufficient to view the episode in question simply as a patchwork of diverse generic elements or learned borrowings. As we shall now see, the pastoral, elegiac, and epic topoi, like the allusions to Theocritus and Homer, that comprise this passage, do not retain their discrete, univocal identity, but work in dialogue to produce a generically innovative rendition of the story.

\section{GENERIC TOPOI AND ALLUSIVE ARTISTRY}

Traditionally, of course, the various generic topoi that appear in this episode have been regarded not only as discrete, but as very different in their relative importance. Most critics have paid little attention to epic and elegiac elements, characterizing the episode as an essay in the pastoral mode. Solodow, in surveying a number of Ovidian episodes that he takes to represent different genres, notes that Polyphemus' lovesong is "impressive for its pastoral quality." 28 Comparable judgments about the essentially pastoral character of the Cyclops' serenade

${ }^{27}$ The role of humor, parodic or otherwise, in the Metamorphoses, has been a major interpretive stumbling block. Some form of humor is present in nearly every episode; but too often critics have felt it their job to point it out and to press no further: for examples see below, note 32. Galinsky (note 4 above) 158-209 (and cf. 147, 244), represents a more balanced view. The episode that we are considering is, in many respects, hilariously funny. But, in order to clarify other, neglected aspects of its character, I will not be at pains to emphasize this obvious one.

${ }^{28}$ Solodow (note 3 above) 22. 
are not uncommon. ${ }^{29}$ Such conclusions place excessive weight on the fact that the Ovidian episode derives from a Theocritean original and makes use of pastoral topoi. This tendency is made more understandable by the fact that most of the pastoral motifs that Ovid employs here undergo a process of auxesis. For instance, where the Theocritean Cyclops praises Galatea's beauty in four comparisons occupying two lines (20-21), Ovid's lovesick monster makes fifteen comparisons occupying a full nine lines (789-97). When he makes music, he uses not a conventional, nine-reeded Pan pipe, but one of a hundred reeds (784). Theocritus' Cyclops pastures a thousand sheep (34); Ovid's cannot count his flocks-only a poor man, he scoffs, could do so (823-24). He will say only that they are many, and say it repeatedly (multae . . multas . . multae 821-22). Thus, according to Solodow, "with these exaggerations and other references Ovid both recreates and plays with pastoral." 30 The result is a conception of the episode as "hyper-pastoral" 31 or, if not sincerely pastoral, then as a spoof on the pastoral mode. ${ }^{32}$

It is in a sense hardly possible to study this passage without using Theocritus' eleventh Idyll as the main point of reference. Indeed, we have already employed this procedure, which serves the interest of expediency while addressing directly the scholarly status quo, and we shall continue to do so. But at the same time, for reasons made clear at the beginning of this paper, our aim is to move beyond the notion that Ovid conceived the episode primarily in terms of pastoral or any other single genre, and that all other influences are at best secondary. Thus we should not view Ovid's version as essentially an imitation cum variatione of a Theocritean original. Similarly, we cannot start with the assumption that the Metamorphoses is a poem in the epic meter, and that we should therefore think of the epic genre as the primary matrix in which the episode was shaped; or that, since most of Ovid's career was

${ }^{29}$ E.g., Otis, Ovid as an Epic Poet ${ }^{2}$ (Cambridge 1970) 280; Galinsky (note 4 above) 135.

${ }^{30}$ Solodow (note 3 above) 22.

${ }^{31}$ E. J. Kenney in Ovid, Metamorphoses, tr. A. D. Melville (Oxford 1986) 453 ad 13.784.

${ }^{32}$ Bömer (note 24 above) vol. 6, 406 speaks of the episode as "burlesque" rather than as straight “bucolic.” J.-M. Frécaut, L'Esprit et l'humor chez Ovide (Grenoble 1972) 124 , sees Ovid as borrowing the element of parody from Theocritus along with everything else, speaking of the episode "comme une caricature du genre pastorale, alors que l'idylle XI de Theocrite, qui a servi de modèle." 
devoted to various elegiac forms, we must therefore regard the elegiac sensibility of the passage as its generic core. Unless we put such ideas aside, a balanced assessment of the episode's generic polyphony will be impossible. The basic situation in which Ovid's Polyphemus finds himself is that of the typical elegiac lover. But despite his situation and his pastoral surroundings, he cannot hide those qualities that make him equally a figure of heroic epos. The humor of his courtship and the poignancy of Acis' death co-exist in a generic hybrid that derives in equal measure from elegy, pastoral, and epic.

To return to the matter of auxesis: a more balanced assessment would regard this procedure not simply as an incongruous and therefore comic way of referring to a pastoral model, but as an element of dialogue between that model and a more "elevated" and heroic exemplar. If pastoral represents the stylistic genus tenue and epic the genus grande, then we may consider Ovid's grotesque inflation of pastoral motifs a product of the confrontation between the two genres. It is no accident, then, that the vast scale of things in this pseudo-pastoral landscape relates in every case directly to Polyphemus, the violent shepherd.

This is the case even when Ovid adds to the apparently pastoral ambience of the episode. When Galatea describes her would-be lover as he takes his place on a promontory overlooking the sea to serenade her (778-88), the setting is similar to that of Idyll 11. Polyphemus is followed by his sheep (781), ${ }^{33}$ and even plays Pan pipes (784), a detail absent from Theocritus. His music, designated as pastoria sibila (785), is heard by landscape and seascape alike (785-86) - not to mention by Acis and Galatea (786-88). All these details are usually said to establish the pastoral character of the passage. But all are complicated by dissonant elements generally of an elevated or heroic nature. To begin with, Polyphemus is still ferus (780). Accompanied by his flocks, he seems more the shepherd than his Theocritean counterpart, who stands alone on his promontory; further, he is provided with the shepherd's badge, a baculus (782). Surprisingly, however, these bucolic details seem to have been inspired not by Theocritus, but by other portrayals of the Cyclops. Here is Vergil: (12).

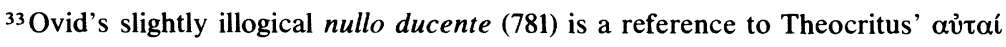


vix ea fatus erat summo cum monte videmus ipsum inter pecudes vasta se mole moventem pastorem Polyphemum et litora nota petentem, monstrum horrendum, informe, ingens, cui lumen ademptum. trunca manum pinus regit et vestigia firmat; lanigerae comitantur oves.

Aeneid 3.655-60

Vergil's Polyphemus is the Homeric monster presented almost sympathetically after his disastrous encounter with Odysseus, ${ }^{34}$ but is notable, like Homer's Cyclops, primarily for his size and ferocity. $\mathrm{He}$ is, however, emphatically a shepherd (pastorem 657) surrounded by his flocks, a detail that Vergil mentions twice $(656,660)$. Moreover, the staff carried by Vergil's monster is actually a pine trunk (659). This idea was inspired by Homer: the olive stake that Odysseus sharpened and used to blind the monster was a staff that he found lying by the sheep pen, a staff that he and his men judged to be the size of a mast for a deepseagoing ship of twenty oars (Od. 9.319-24). Ovid thus alludes to both the Vergilian and Homeric passages: his Cyclops' staff is a pine big enough to be fitted out with tackle and used as a ship's mast (782-83). His sheep too are, so to speak, Vergilian sheep, lanigerae pecudes (781). The compound is found twice in the Aeneid passage (642, 660); it does not occur in the Eclogues. ${ }^{35}$ Finally, when Ovid's Polyphemus sings, the mountains and the waters respond to his song:

senserunt toti pastoria sibila montes,

senserunt undae. . . .

Metamorphoses $13.785-86$

At first glance, these lines look like an instance of the pathetic fallacy in its pastoral guise. ${ }^{36}$ The anaphora is a regular feature of the motif, ${ }^{37}$ and the meaning of pastoria sibila (785) could hardly be clearer. senserunt is not quite the right word, however, The landscape did not "hear" or "answer" Polyphemus' song, but "felt" it. The metrical shape of the

${ }^{34} \mathrm{~A}$ note of sympathy is indeed not absent from the Homeric episode when Polyphemus pathetically addresses the ram bearing Odysseus out of the cave (Od. 9.447-60). Noticing that the ram is leaving last rather than leading the flock, the monster conjectures that he must be downcast at his master's evil fate.

${ }^{35}$ It is found otherwise at Georgics 3.287, an elevated context, and Aeneid 7.93. Compounds in general are uncommon in the Eclogues.

${ }^{36}$ The motif is not found in Idyll 11, but it is latent in Vergil's imitation in Ecl. 2.

${ }^{37}$ See Bömer (note 24 above) ad loc. with references. 
two successive lines begun by senserunt is also telling: Ovid does not often begin a line with five long syllables, still less two lines in a row. Here he does so for the second time in twenty-five lines. The first passage is Galatea's description of the monster's appearance:

horrendum silvis et visus ab hospite nullo

impune et magni cum dis contemptor Olympi. . . .

The repetition of such unusual, ponderous sound-effects, particularly in Ovid's precipitous narrative style, is striking. Moreover, Galatea stresses that "all the mountains" (toti . . montes 785) felt the song, and that she "took it in from afar" (procul auribus hausi 787). These details, like Polyphemus' absurd hundred-reeded pipes (784), suggest that what Galatea heard was not the sweet music of a conventional Theocritean shepherd, but rather a truly Cyclopean racket. Returning to Vergil, we discover that as the Trojans put to sea to avoid an encounter with the monster, Polyphemus bellows at the sound of a ship moving in the water:

clamorem immensum tollit, quo pontus et omnes intremuere undae, penitusque exterrita tellus Italiae curvisque immugiit Aetna cavernis.

Aeneid 3.672-74

Thus, like the points mentioned previously, what looked at first to be a standard allusion to the pathetic fallacy in its pastoral guise upon examination betrays a powerfully epic orientation.

These transformations are paralleled by numerous other details throughout the episode involving not only pastoral, but elegiac motifs as well. In an effort to improve his appearance, Polyphemus, as noted above, ${ }^{38}$ follows advice that Ovid elsewhere recommends to the young Roman gentleman on the make:

iamque tibi formae, iamque est tibi cura placendi, iam rigidos pectis rastris, Polypheme, capillos, iam libet hirsutam tibi falce recidere barbam et spectare feros in aqua et componere vultus.

Metamorphoses 3.764-71

sit coma, sit scita barba resecta manu.

Ars amatoria 1.518

${ }^{38}$ See above and also note 18. 
The fearsome Homeric monster not only acts out a situation derived from erotic elegy by way of Theocritean pastoral, but actually follows the advice given by Ovid himself in his guise as praeceptor amoris. In addition to the erotodidactic motif of cultus formae, Ovid's diction points to the world of love poetry. capilli (765), the most frequent word for "hair" in the Metamorphoses, is an example of how elegiac traditions informed Ovid's only surviving essay in the epic meter. ${ }^{39}$ The word is simply part of Ovid's normal vocabulary in the poem, a fact that makes it impossible to attach special significance to its occurrence here per se. In all occurrences, however, the word retains its "elegiac" tone; and its treatment in this passage continues to point out Polyphemus' generic complexity. Where elegiac tresses are typically soft and flowing, Polyphemus' are rigidi. ${ }^{40}$ The phrase capilli rigidi is thus a virtual oxymoron defining a dichotomy similar to that regularly drawn between elegiac and heroic verse. ${ }^{41}$ Finally, and most obviously, the hirsute monster must take drastic measures to counterfeit the look that he desires. His articles de toilette consist, not of combs and scissors, but of rakes and scythes. This humorous conceit again stresses Polyphemus' Cyclopean proportions, and thus problematizes his appearance in, this time, an elegiac role. ${ }^{42}$

Similarly, in boasting of his own appearance Ovid's Cyclops is

${ }^{39}$ On the distribution of capillus/coma/crinis in Latin poetry see B. Axelson, Unpoetische Wörter: ein Beitrag zur Kenntnis der lateinischen Dichtersprache, Publications of the New Society of Letters at Lund 29 (Lund 1945) 51, with the further remarks of Knox (note 4 above) 33 .

${ }^{40}$ See, e.g., Tibullus 1.8.9, 3.8.9; Propertius 2.1.7; Ovid, Ars 3.709. I can find only two other passages in which capillus is modified by rigidus, both of them Ovidian. The first (Ars 1.517) is the passage on good grooming partially cited above, note 18 . The second (Met 10.425 ) is the sort of exception that proves a rule: when Myrrha confesses to her nurse about her passion for Cinyras, the old woman's hair becomes stiff with horror. Here an appreciation of Ovid's diction lends impact to the nurse's thoroughly conventional reaction, since capilli are almost by definition never rigidi. For the thematic contrast, cf. Martial 10.20.20-21.

${ }^{41}$ The opposition between "hard" and "soft" poetry is of course paralleled by many similar ones (large and small, strong and weak, heavy and light, etc.): cf. Propertius 2.34.41-44, 3.1.19-20; Ovid, Amores 3.1.41-46; Met. 5.257 and Fasti 3.456 (with the discussion of Hinds [note 1 above] 21-23 and 141, n. 58); Tristia 2.327-40 (with the discussion of Walter Wimmel, Kallimachos in Rom. Die Nachfolge seines apologetischen Dichtens in der Augusteerzeit, Hermes Einzelschriften, Heft 16 [Wiesbaden 1960] 297-98).

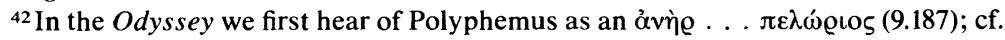
190-92). His enormous size and strength are mentioned repeatedly throughout Odysseus' tale of their encounter, and appear frequently in the Ovidian episode, as we shall see. 
obsessed with size. This point contrasts sharply with Idyll 11, in which Theocritus' monster recognizes that his looks put Galatea off:

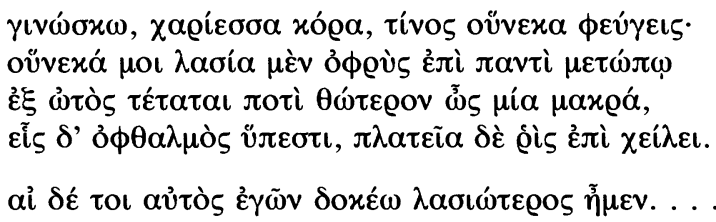

Idyll 11.30-33

Ovid begins with a reference to Theocritus' other Polyphemus idyll, once again by way of Vergil (this time the Eclogues). ${ }^{43}$ But Ovid's Cyclops admires different qualities from those of Theocritus' pastoralized monster. Rather than comely cheeks, a single lovely eye, and gleaming teeth, he boasts of his immense size, his abundance of stiff and shaggy hair, his bristling beard, and his one huge eye (842-53). The emphasis is consistently on size and quantity rather than, as in Theocritus and implicitly in Vergil, on quality. Moreover, the specific terms in which he boasts are especially revealing. First, his size:

adspice sim quantus! non est hoc corpore maior Iuppiter in caelo-nam vos narrare soletis nescio quem regnare Iovem. . . .

Metamorphoses $13.842-44$

The blasphemous comparison with Jupiter is perhaps inspired by the belief of Vergil's Corydon that his beauty could stand comparison with that of Daphnis, the pastoral god. ${ }^{44}$ But Polyphemus translates the pastoral comparison into an epic/heroic equivalent. To intensify the blas-

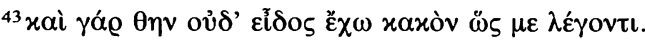

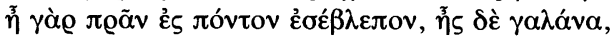

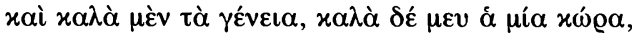

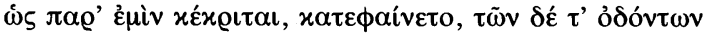

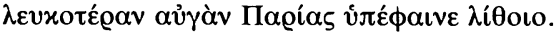

nec sum adeo informis: nuper me in litore vidi, cum placidum ventis staret mare. non ego Daphnin iudice te metuam, si numquam fallit imago.

certe ego me novi liquidaeque in imagine vidi nuper aquae, placuitque mihi mea forma videnti. ${ }^{44} \mathrm{As}$ he is portrayed in Eclogue 5.56-80. 
phemy, he casts doubt on Jupiter's very existence, a reference to the character's traditional Homeric disregard for Zeus Xenios. ${ }^{45} \mathrm{He}$ next boasts of his hirsute nature:

coma plurima torvos

prominet in vultus umerosque, ut lucus, obumbrat

nec mea quod rigidis horrent densissima saetis

corpora turpe puta; turpis sine frondibus arbor,

turpis equus, nisi colla iubae flaventia velent;

pluma tegit volucres, ovibus sua lana decori est:

barba viros hirtaeque decent in corpore saetae!

Metamorphoses 13.844-50

Again he stresses that he has so great an abundance of hair, and does so to the point of hyperbole: his hair throws a shadow like that of a grove over his head and shoulders. His face is fierce (torvos . . . vultus 84445) and bearded (barba 850), both points in sharp contrast to the de-

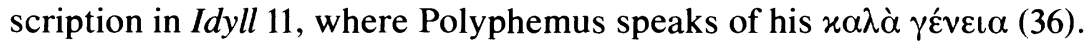
The generally pastoral tenor of his comparisons (trees 847, birds and sheep 849-but cf. horses 848) is ludicrous when put to the service of this sophistic argument. The monster speaks in pastoral terms, but distorts their conventional meaning and betrays his lack of sympathy with them. In praising his eye, he abandons these terms and turns to a very different field of comparison:

unum est in media lumen mihi fronte, sed instar ingentis clipei. quid? non haec omnia magnus sol videt e caelo? soli tamen unicus orbis! Metamorphoses 13.851-53

Again the contrast with Theocritus is instructive. In Idyll 6, Polyphemus refers more delicately to the fact that he has only one eye; but like his cheeks it is lovely, and in naming it he uses a rather touching term of

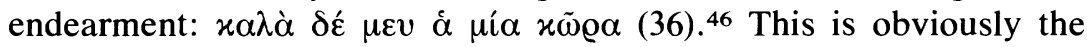
language of erotic poetry. In Metamorphoses, Polyphemus grants more frankly that having only one eye is a defect, but argues that his one eye is as big as a huge shield - and therefore, presumably, preferable to any pair of normal eyes. The shield as a point of comparison is obviously

\footnotetext{
${ }^{45}$ On this motif see further below.

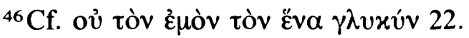


martial and heroic, rather than elegiac or pastoral. Indeed, though there is no reason to suspect a specific allusion here, Ovid's transformation of Theocritus here is the converse of Theocritus' sophisticated translation of the great shield of Iliad 18, an icon of the heroic world, into a humble cup, itself an icon of the pastoral world, in Idyll 1.

Having effected this reversal, the Ovidian Polyphemus goes even further with another, truly hyperbolic comparison of cosmic proportions. Having only one eye, Polyphemus claims, he is like the sun, which sees all things. The hyperbole itself and the cosmic tenor of the comparison mark it as a trope suited to the high style of heroic epos. ${ }^{47}$ But the comparisons with shield and sun are not just heroic in general; together, they have a specific referent, again in Vergil's Polyphemus episode:

telo lumen terebramus acuto ingens quod torva solum sub fronte latebat, Argolici clipei aut Phoebeae lampadis instar, et tandem laeti sociorum ulciscimur umbras.

Aeneid 3.635-38

This constant emphasis on Polyphemus' size is absent from Theocritus, who actually suppresses this feature of Homer's account ${ }^{48}$ in order to habilitate the Cyclops to the pastoral and elegiac requirements of the genus tenue. Vergil's Polyphemus retains his Homeric dimensions. Ovid's version is, unmistakably, a hybrid, a creature who could not possess his distinctive mixture of traits without drawing upon previous epic and pastoral exemplars.

Another telling instance of dialogism with respect to topoi involves Ovid's handling of the mise-en-scène. Sicily, as noted above, is of course the homeland of Theocritus and the setting of Idyll 11; hence the presumption that Ovid's Sicilian setting alludes to a typically Theocritean pastoral world. This presumption ignores one crucial fact. Already in the Metamorphoses Sicily has been presented as a distinctly unpastoral place. The song of Calliope in Book 5 begins with a brief hymn to Ceres (341-45) and then continues with a description of Sicily,

${ }^{47}$ For this type of hyperbole as a device used to produce ekplexis, pathos, and a sense of the sublime, see P. R. Hardie, Virgil's Aeneid: Cosmos and Imperium (Oxford 1986) 241-92.

${ }^{48}$ See above, note 42. 
the setting for most of the ensuing narrative. The specific terms of this description are highly significant:

vasta Giganteis ingesta est insula membris

Trinacris et magnis subiectum molibus urget

aetherias ausum sperare Typhöea sedes.

nititur ille quidem pugnatque resurgere saepe,

dextra sed Ausonio manus est subiecta Peloro

laeva, Pachyne, tibi, Lilybaeo crura premuntur, degravat Aetna caput; sub qua resupinus harenas eiectat flammamque ferox vomit ore Typhoeus.

Metamorphoses 5.346-53

Several elements of this description mark Sicily as an appropriate setting not for pastoral, but for heroic narrative. Instead of the inviting landscape, the geographic situation of the whole island is described, a procedure that suggests not the intimate scale of the humbler genre, but a setting for the grandiose, heroic events of epic narrative. One of the island's natural wonders, Mt. Aetna, sublime in its destructive majesty, is mentioned prominently. Finally, the volcano's fury is explained by the myth of Typhoeus, the unsuccessful rebel whose attempt to overthrow the Olympians, like the similar attempts of the Giants, the Titans, the Aloidae, et al., appears continually in Augustan poetry as an ideal heroic theme ${ }^{49}$ Everything in this description prepares the reader for a narrative of heroic character. Comparison with the corresponding passage of the Fasti is instructive:

terra tribus scopulis vastum procurrit in aequor

Trinacris, a positu nomen adepta loci,

grata domus Cereri. multas ea possidet urbes, in quibus est culto fertilis Henna solo.

frigida caelestum matres Arethusa vocarat; venerat ad sacras et dea flava dapes.

filia, consuetis ut erat comitata puellis, errabat nudo per sua prata pede.

${ }^{49}$ E.g., Horace, Carm. 2.12.6-9; Propertius 2.1.19-20 and 39-40, 3.9.48-49; Ovid, Amores 2.1.11-22; Met. 10.148-54; Tr. 2.61-76 and 327-36. See S. G. Owen, P. Ovidi Nasonis Tristium liber secundus (Oxford 1934) 63-81; D. C. Innes, "Gigantomachy and Natural Philosophy," CQ 29 (1979) 165-71; Hardie (note 47 above) 403, s.v. "Typhonomachy." 
valle sub umbrosa locus est aspergine multa uvidus ex alto desilientis aquae.

tot fuerant illic quot habet natura colores, pictaque dissimili flore nitebat humus.

Fasti 4.419-30

Sicily remains here the three-cornered isle (419-20; cf. Met. 5.346). The motif of topographical description, however, receives less emphasis than in Metamorphoses 5, while Aetna and Typhoeus do not appear at all. Instead, the whole island is described as a locus amoenus, Ceres' pleasant home (421), with well-watered valleys where maids can wander barefoot, picking flowers (425-30). The differences between these passages reflect Ovid's attunement to the divergent conventions of epic and elegiac narrative. ${ }^{50}$

Of course, we need not assume that Ovid, having established Sicily as a place with heroic associations in Metamorphoses 5, will maintain a uniform attitude throughout the poem. Indeed, if we now turn to the description of Sicily in Metamorphoses 13, it becomes difficult not to think of both of the other passages in which Sicily is described. ${ }^{51}$ Aeneas and his band, sailing en route to Italy, land on Sicily:

... intrant

Sicaniam. tribus haec excurrit in aequora pennis, e quibus imbriferos est versa Pachynos ad Austros mollibus expositum Zephyris Lilybaeon, ad Arctos aequoris expertes spectat Boreamque Peloros.

The phrase tribus haec excurrit in aequora pennis (723) recalls terra tribus scopulis vastum procurrit in aequor (Fasti 4.419). The three capes mentioned by name, moreover, clearly echo the description of Sicily in Metamorphoses 5. There was no reason, other than to establish a link between the two passages, to mention these places by name; they are irrelevant either to the preceding narrative of Aeneas' wanderings or to the subsequent one of Polyphemus' passion. Again, however, as in the Fasti description, Aetna and Typhoeus disappear; but here, in contrast

\footnotetext{
${ }^{50}$ See Richard Heinze, Ovids elegische Erzählung, Berichte über die Verhandlungen der Sächsischen Akademie zu Leipzig, Philologisch-historische Klasse, 71.7 (Leipzig 1919) 8, with the cautionary remarks of Hinds (note 1 above) 114.

${ }^{51}$ It is obviously immaterial in what order the three passages were composed. I would guess that Ovid worked on all of them simultaneously, or else revised the earlier in light of the later ones, in order to establish verbal and imagistic links among them.
} 
to Fasti 4 , they are replaced by a different destructive wonder, or rather by a pair of them, Scylla and Charybdis. The introduction of these monsters provides another opportunity for sophisticated self-reference. According to Ovid, Aeneas and his men put in at Zancle (Met. 13.729). This, the former name of Messina, is not at all common in any type of ancient literature. ${ }^{52}$ In particular, it is not mentioned in any other account of Aeneas' wanderings, including Vergil's. By including it here, then, Ovid signals a departure from his model. He also signals the direction of this departure: the only previous reference to Zancle in surviving Latin verse is in the elegiac Persephone narrative of the Fasti (4.499), also in connection with Scylla and Charybdis. And yet, by way of introducing this epic pair in the Metamorphoses, Ovid avails himself of a Vergilian reference:

Scylla latus dextrum, laevum inrequieta Charybdis infestat. . . . Metamorphoses 13.730-31 dextrum Scylla latus, laevum inplacata Charybdis obsidet. ...

Aeneid 3.420-21

By this web of allusions, Ovid's description of Sicily in Book 13 leads the reader to expect traces in the ensuing narrative of both the epic/ heroic and elegiac associations of the island that are found in the twin Persephone narratives of Metamorphoses 5 and Fasti 4, as well as the pastoral connotations deriving chiefly from Theocritus.

The dialogic potential of Sicily asserts itself once more as the Polyphemus episode draws to a close. Ovid of course follows Theocritus in exploiting the generically ambivalent element of fire. Theocritus plays on the erotic metaphor of burning with love to create a bathetic allusion to Polyphemus' fate in the Odyssey, where Odysseus burns out the monster's eye with a glowing, sharpened stake (9.371-97). The Theocritean monster so loves Galatea that he would make for her the ultimate sacrifice:

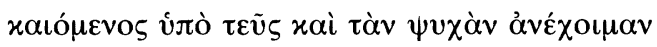

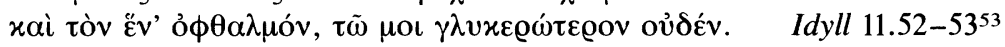

${ }^{52}$ See W. Pape and G. Benseler, Wörterbuch der griechischen Eigennamens ${ }^{3}$ (Braunschweig 1911; repr. Graz 1959), s.v.

${ }^{53}$ Ovid too treats of the loss of Polyphemus' eye, less obliquely than Theocritus, to 
Ovid also, as we have noted, toys with the idea of Polyphemus as a typically elegiac lover in a pastoral setting: uritur oblitus pecorum antrorumque suorum (763). Later Polyphemus himself invokes the motif of burning with passion, but reveals that the fires that torment him have a distinctly unlovely character: he burns ever hotter, as if Aetna itself had been put into his chest:

uror enim laesusque exaestuat acrius ignis. cumque suis videor translatam viribus Aetnam pectore ferre meo-nec tu, Galatea, moveris!

Metamorphoses 13.867-69

be sure, but no less playfully. Warned by the seer Telemus that he will lose his eye to Ulysses, the Cyclops replies cheerfully that he has already lost it to another (770-75):

Telemus Eurymides, quem nulla fefellerat ales, terribilem Polyphemon adit, "lumen"que "quod unum fronte geris media rapiet tibi" dixit "Ulixes." risit et "o vatum stolidissime, falleris" inquit: "altera iam rapuit."

The passage clearly alludes to Homer:

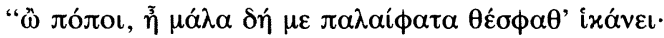

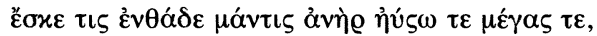

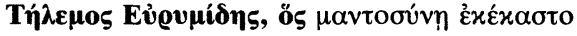

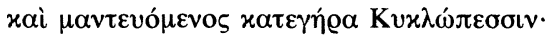

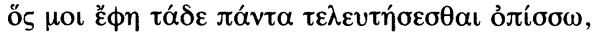

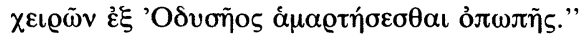

Odyssey $9.507-12$

Telemus of course also is named in Theocritus' other Polyphemus idyll:

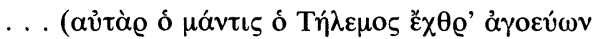

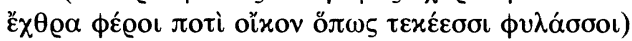

Idyll $6.23-24$

But Ovid's emphatic placement of the prophet's name in its Homeric sedes clearly refers the reader to the relevant passage of the Odyssey. Note also that Polyphemus' punning retort introduces another of the erotic elements that leaven his epic style. Vergil, in mentioning the loss of Polyphemus' eye, uses the colorless verb adimere:

monstrum horrendum, informe, ingens, cui lumen ademptum

Aeneid 3.658

Ovid, by using the verb rapere, makes possible a reference to a common elegiac motif (e.g., Amores 2.19.19, 3.11.48; further references in Bömer [note 24 above] 416 ad loc.). 
This elegiac topos ${ }^{54}$ resembles the Theocritean monster's declaration that he burns with love. But it is also a signal reversal of a motif used by Theocritus elsewhere in Idyll 11. Among the delights that Polyphemus hopes will entice Galatea to forsake the sea and live in his pastoral world, he mentions the cool water that rushes down to him from the snows of Aetna:

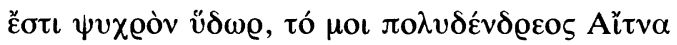

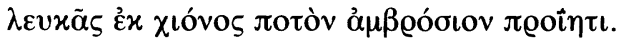

Idyll $11.47-48$

Theocritus' unthreatening Aetna thus takes its place on the generous horizon that embraces the pastoral pleasance. But the Aetna of the Metamorphoses bears very different associations: not gleaming snows and streams of cold water, but seething, pent-up flames.

This imagistic reversal announces a sequence of generic complications leading up to a second, equally significant narrative departure in which Aetna figures once again. No sooner has Ovid's Cyclops mentioned the Aetna that threatens to erupt within him than he rises (surgit 871) and begins to wander (errat 872). Both actions are generically significant. As Polyphemus rises, so does the style of the narrative, from the pseudo-pastoral to the pseudo-heroic level; 55 yet his wandering is typical of the elegiac lover. ${ }^{56} \mathrm{~A}$ simile follows: frustrated in love, Polyphemus is like a bull that has lost its mate to a rival, mad with rage and eager for revenge. The simile is epic in form; indeed, Ovid's inspiration was surely Vergil's description first of Turnus working himself into a fury for the final combat over Lavinia, then the duel itself (Aeneid 12.101-6, 715-24). But Vergil, of course, adapted this simile from his memorable vignette on the same theme in the Georgics $(3.209-41) .{ }^{57} \mathrm{We}$

${ }^{54}$ See A. A. R. Henderson. P. Ovidi Nasonis Remedia amoris (Edinburgh 1979) 102 ad 491, with further references.

${ }^{55}$ Cf. Propertius 2.10.11-12; Ovid, Tr. 2.559, Pont. 3.3.31-32. Vergil's language in the Eclogues provides an additional point of reference. The word surgamus (75), given its position near the end of the collection's final poem, suggests that the poet has finished with the humbler genus tenue, and may have "greater" things in mind: see William Berg, Early Virgil (London 1974) 189-90, and Duncan F. Kennedy, "Shades of meaning: Vergil, Eclogue 10.75-77," LCM 8 (1983) 124.

${ }^{56} \mathrm{Cf}$. the wandering of Gallus at Ecl. 6.64, with the remarks of Putnam, Virgil's Pastoral Art. Studies in the Eclogues (Princeton 1970) 211-12.

${ }^{57}$ See the discussions of Friedrich Klingner, Virgil: Bucolica, Georgica, Aeneis (Zürich-Stuttgart 1967) 289; Ward W. Briggs, Jr., Narrative and Simile from the Georgics 
may thus read the Ovidian simile as an appropriation of Vergil's earlier dialogue between the georgic and the heroic world. Then Polyphemus catches sight of Acis with Galatea in his arms. He gives a cry such as befits a maddened Cyclops, swearing that Acis and Galatea have enjoyed their final tryst; and then kills Acis by hurling at him a piece of a mountain.

Two details here are especially significant. First, the manner in which Polyphemus kills Acis looks to epic prototypes, as noted above. The phrase that describes his weapon, partemque e monte revulsam (882) not only underlines Polyphemus' superhuman size and strength, but actually corresponds to a phrase that Homer uses in his Polyphe-

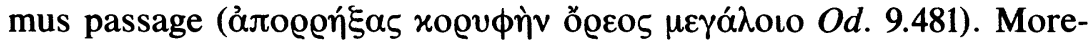
over, it ironically recalls the boastful description of his vast holdings with which Ovid's monster had earlier attempted to impress Galatea (sunt mihi, pars montis, vivo pendentia saxa / antra 810-11). The phrase that he had used to indicate the size of his pastures, a motif borrowed from Theocritus ${ }^{58}$ and then subjected to auxesis, is now applied to the weapon that he hurls heroically against his foe, a motif borrowed from Homer. Second, the cry that Polyphemus gives frightens Aetna itself (clamore perhorruit Aetna 877). Thus the metaphorical Aetna within the lovesick monster results in actions that cause the actual volcano to tremble. Again we may compare Vergil:

clamorem immensum tollit, quo pontus et omnes intremuere undae penitusque exterrita tellus

Italiae, curvisque immugiit Aetna cavernis.

Aeneid 3.672-74

Here the waves and the distant land of Italy tremble in fear at Polyphemus' roar, while Aetna echoes in sympathetic response. ${ }^{59}$ In Ovid, however, even the volcano recoils in horror. This point is especially

\footnotetext{
in the Aeneid, Mnemosyne Supplement 58 (Leiden 1980) 48-50; G. N. Knauer, "Vergil and Homer," ANRW 31.2 (1981) 914-18.

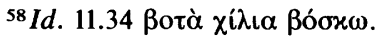

${ }^{59} \mathrm{Hirtzel}$ and Mynors are unusual in punctuating this passage with a comma after undae 673 and none after Italiae 674 , producing a reading that differs from mine. Heyne and Conington, who put commas in both places, are more representative: the former takes exterrita as attributive to tellus, which with undae becomes the compound subject of contremuere; the latter takes exterrita as standing for a finite verb. Either interpretation allows for a disjunction between, on the one hand, the frightened reaction of land and sea generally, and, on the other, the sympathetic echo of Aetna.
} 
significant in light of an earlier observation made by Galatea. In describing her unwanted suitor, she notes that the Cyclops is a thing of fright to the landscape that he inhabits; specifically, he is inmitis et ipsis / horrendus silvis (759-60). silvae, of course, stands regularly in Latin for the typical pastoral environment. ${ }^{60}$ But Galatea mentions this environment only to point out that Polyphemus makes it shudder and recoil in horror. The typical pastoral hero, in contrast, lives in deep sympathy with his rustic home. He, for his part, enjoys its pleasures, while the sentient landscape hears his songs, feels his joy and pain, flourishes or dies with him. ${ }^{61}$ Polyphemus frightens the silvae, a clear sign to Galatea that he is of another world entirely. But at the end of the episode, the monster's angry bellow causes even Aetna, the conventional symbol of an epic landscape, to shudder as the pastoral silvae had done before. ${ }^{62}$

These two motifs are complementary. On the one hand, the similar phrases pars montis $(810)$ and partemque e monte revulsam (882) denote both Polyphemus' pastoral holdings and the weapon that he uses to murder Acis, thus marking him as a creature of two worlds. On the other hand, the motif of the two landscapes, pastoral and epic, that shudder at his actions, mark him as an outcast from both worlds. Thus Ovid's Cyclops is a creature of both the pastoral and epic genres, and, at the same time, of neither.

It should be clear that neither Ovid's inflation of the familiar pastoral world nor his complex treatment of the story's Sicilian setting can

${ }^{60}$ E.g., Vergil, Ecl. 6.2:

prima Syracosio dignata est ludere versu

nostra neque erubuit silvas habitare Thalia

and cf. $1.5,2.60-62,4.3,5.28,5.58,6.2,8.58,10.8$. As the collection opens, Meliboeus addresses Tityrus thus: silvestrem tenui Musam meditaris avena (1.2). Cf. Bömer (note 24 above) 413 ad loc., who sees a special application to pastoral qua love poetry (his reference to Galinsky should read "II" rather than "I").

${ }^{61}$ Most representative of this tendency is Daphnis in Idyll 1: in his final hours the shepherds fail to graze their flocks, the wild beasts, the mountains and the trees themselves mourn him (70-75), while he himself prays that confusion seize the pastoral land-

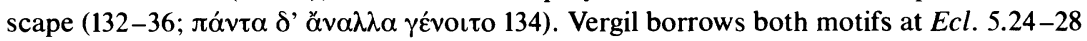
and 36-39. Similarly, in Tityrus' absence the saddened Amaryllis continually invokes the gods and fails to harvest her apples, while the very pines, fountains, and groves call out for their master ( $E c l$. 1.36-39).

${ }^{62} \mathrm{Cf}$. the trembling of Aetna discussed above. 
be understood in conventional generic terms. There can be no question of individual elements borrowed from different genres, each retaining its pastoral, epic, or elegiac character. Instead, each of these elements takes on a new character, provisional and unique to this telling of this story.

The same tendency that we have observed in respect of the episode's more general features extends to many details as well; but enough has been said to indicate how Ovid's generic dialogue functions at this level. We may now turn to examine the polyphonic character of the narrative itself.

\section{THE NARRATIVE CONTEXT}

We have already seen that the existence of a rival, the emphasis given to Polyphemus' epic background, and other factors give the Ovidian episode a very different character from that of Idyll 11. In what follows, we shall examine the way in which Ovid fits the episode into his carmen perpetuum and how his method of doing so underlines its generic sophistication. This process will in turn shed light on the generic character of the poem as a whole and permit us to relate the question of genre to a number of larger interpretive issues.

Again Idyll 11 provides a useful starting point. Theocritus gives us Polyphemus' song virtually as a complete poem. Its context is provided in an introduction of eighteen lines and a two-line conclusion, passages which correspond to sections of the Ovidian episode.$^{63}$ But this is the only context for Idyll 11 of which we can be certain. There is no larger narrative context. ${ }^{64}$ With the Metamorphoses the situation is far different. Ovid gives us Polyphemus' song not as a short independent poem, but as an episode embedded in a long poem of extraordinary variety and

${ }^{63}$ We shall return to this point below.

${ }^{64}$ We may allow that Theocritus' other poetry provides a broader context for interpretation, but whether Idyll 11 was embedded in a poetry book created by the author himself-as is the case with Vergil's imitation of this poem in Eclogue 2-and, further, what else that book might have contained, are matters of pure conjecture.

On the possibility that Theocritus did collect and arrange his poems, see V. Di Benedetto, "Omerismi e struttura metrica negli idilli dorici di Teocrito," ASNP 25 (1956) 48-60; Gilbert Lawall, Theocritus' Coan Pastorals (Washington 1967); John Van Sickle, "Poetica Teocritea," QUCC 9 (1970) 82-97; "Theocritus and the Development of the Conception of the Bucolic Genre," Ramus 5 (1976) 18-44 (see 31-34, 42, n. 81); The Design of Virgil's Bucolics (Rome 1978) 106. 
complexity. It is easy to lose sight of the fact that its immediate context is a series of stories that make up an episode in the "Little Aeneid" (13.623-14.608), in both theme and literary background one of the most epic portions of the Metamorphoses. But whereas the preceding narrative concerns the actual deeds of the Trojan wanderers, this lengthy sequence relates only their landing (13.729) and departure (14.72-74) in the briefest possible way. The intervening episode consists entirely of "digressions" from the main narrative. Here Ovid relates stories not found in the corresponding Vergilian narrative of Aeneas' wanderings, stories that owe a great deal to other, bucolic and elegiac, sources. Moreover, the theme of the stories related during this episode-those

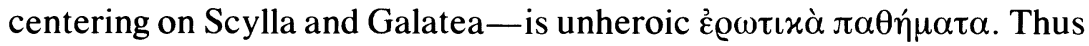
the episode presents itself to the reader as a kind of erotic interlude in the heroic adventures of Aeneas, or even as a replacement for one of these adventures. Its relationship to its context therefore confronts the reader with the issue of divergent, even antithetical generic traditions; and the confrontation is heightened when these traditions become the constitutive generic elements of the episode itself.

Finally, in addition to the specific motifs that we have discussed, the very length of the episode illustrates the pull of differing generic influences in this context. In structural terms, Ovid follows the same pattern used by Theocritus, as noted above; but, like Polyphemus himself and his enormous trappings, every section of the original has been expanded. Idyll 11 begins with eighteen lines of introduction, devotes sixty-one lines to Polyphemus' lovesong, and concludes with a twoline coda for a total of eighty-one lines. Ovid's version includes fortynine lines of introduction (740-88), a song comprising eighty-one lines (789-869), and a thirty-line conclusion (870-99). His episode thus extends to one hundred sixty lines, making it about twice the length of its Theocritean model. This fact is unusual and important. If we compare other passages of Ovidian imitation to their originals, we find that it was this poet's normal practice, like that of all Augustan poets, to condense his models. For example, Ovid's two Persephone narratives (Met. 5.341-571 and Fasti 4.417-620) are shorter combined than the Homeric Hymn to Demeter (495 lines). Not that compression is invariable: Ovid's "Plague of Aegina" (7.523-642) and "Erysichthon" (8.738-878) are both slightly longer than their respective models, Vergil's "Plague of Noricum" (Georgics 3.478-566) and Callimachus' Hymn to Demeter (138 lines). But the auxesis observable in the Polyphemus episode is, I believe, unparalleled. An expansion on this scale would call attention to itself under any circumstances. In a context like the "Little Aeneid," in 
which Ovid summarizes the action of Vergil's twelve books and more in only 954 lines, the force of this effect increases exponentially.

Our analysis has revealed that the "elevated" surroundings of the Trojan saga have left their mark on the Polyphemus episode in a number of specific ways. But we must not overstate this point, for the effect is felt in both directions. Ovid's "Aeneid" is itself rich in generic sophistication. The comical song of the lovesick Cyclops is just one episode woven into the narrative of Aeneas' wanderings that stands in pointed contrast with the austere heroicism of the Aeneid theme. Part of Ovid's strategy in relating these episodes is to temper the adventurous and elevated character of this material. Further, the idea, borrowed from Theocritus, of casting Polyphemus, one of the great figures of epic poetry, in the role of an elegiac/bucolic lover is an obvious emblem of the heroic brought down to a humbler scale. But just as Ovid's "Aeneid" narrative distinguishes itself in subtle, genre-conscious ways from the consummately heroic rendition of Vergil, so does the Polyphemus narrative distance itself from its models. The enclosed narrative and its frame exist in a state of generic dialogue, with respect both to their individual generic influences and to one another.

If we recognize these facts, we will begin to understand how the diverse generic elements of this one episode relate to the episode's place in a larger context. In this connection the idea of a dialogue between different genres in the Polyphemus episode is paralleled by a polyphonic relationship between the narrators present both within the episode itself and in the context that frames it. This sort of relationship, as is well known, is one of the essential organizing principles of the poem as a whole. ${ }^{65}$ Thus, to restate an earlier point more broadly, by attending to the generic polyphony of the Polyphemus episode in its

${ }^{65}$ This aspect of the poem has been partially explored by N. G. G. Davis, "Studies in the Narrative Economy of Ovid's Metamorphoses" (Diss. Berkeley 1969). The problem has not yet made a very significant impact on the periodical literature, much less the more recent book-length surveys. For an exception see Sara Mack, Ovid (New Haven and London 1988) 130-36. By way of contrast, the belief of Solodow (note 3 above) 38 that "there is basically a single narrator throughout, who is Ovid himself. The introduction of the other speakers is more formal than consequential; the words heard are those of the poet," is disappointingly retrograde. For the general method, see Vladimir Propp, Morphology of the Folktale, ${ }^{2}$ tr. Laurence Scott, rev. Louis A. Wagner (Austin-London 1968); Todorov, Grammaire du Décaméron (The Hague 1969) and The Poetics of Prose, tr. Richard Howard (Ithaca 1977); Gérard Genette, Narrative Discourse: An Essay in Method, tr. Jane E. Lewin, foreword by Jonathan Culler (Ithaca 1980) and Narrative Discourse Revisited, tr. Jane E. Lewin (Ithaca 1988); Gerald Prince, Narratology: The Form and Functioning of Narrative (Berlin 1982). 
narrative context, we shall gain insight into the overall generic identity of the Metamorphoses.

We may approach the issue of narrative polyphony along the path by which the reader encounters Polyphemus' story. When Aeneas and his followers put in at Zancle, the narrator alerts the reader that the monster Scylla infests the area to their right, while the whirlpool Charybdis occupies the left $(728-31)$. As for description, the latter is dispatched in under a line (731), while to Scylla is devoted a lengthy aetiological narrative (13.732-14.74). It is this narrative that is interrupted as soon as it has begun by the story of Acis, Galatea, and Polyphemus (13.738-899). After Galatea finishes telling this story, the Scylla aetion resumes. Formally, then, Polyphemus' lovesong is a part of Galatea's story, which is an interlude in the story of Scylla, which is itself an episode of the "Little Aeneid." We can best understand the interesting relationship that this nested structure creates by comparison with Idyll 11. In Ovid, the introduction to Polyphemus? lovesong is related not by an authorial narrator, like that of $I d y l l 11$, but by a character in the story-Galatea herself, in fact. This complicates the simpler situation that we find in the idyll, in which "Theocritus" narrates to Nicias a song sung by Polyphemus to Galatea. In Ovid, Galatea relates to another character the song that Polyphemus had once sung to her. Thus the narratee of Polyphemus' lovesong becomes its narrator on another occasion, a sophistication absent from Idyll 11. Further, Galatea's narratee is not Nicias, a doctor and a man of letters, but Scylla, who is herself about to become the subject of another story. Finally, Galatea's tale to Scylla is embedded in a third, much larger narrative context, the story of Aeneas' wanderings. It is only at this level that we encounter the authorial narrator, "Ovid," whose narratee is the reader of the poem. For the sake of clarity, we may represent the three levels of narration in these two poems schematically as follows:

\begin{tabular}{cccc}
\multicolumn{2}{c}{ Idyll 11} & \multicolumn{2}{c}{ Metamorphoses 13} \\
$\begin{array}{c}\text { (narrator) } \\
\text { Polyphemus }\end{array}$ & $\begin{array}{c}\text { Garratee } \\
\text { (narrator) }\end{array}$ & $\begin{array}{c}\text { (narratee) } \\
\text { Galatea }\end{array}$ \\
"Theocritus" & $\left\{\begin{array}{l}\text { Nicias } \\
\text { reader } \\
-\end{array}\right.$ & Gallyphemus & Scylla \\
\hline & & "Ovid" & reader
\end{tabular}

The differences between those who fill the basic narrative roles in the two poems correspond to major differences in the stories them- 
selves. Polyphemus' song, which in Ovid as in Theocritus is narrated by Polyphemus to Galatea, carries similar messages in both poems: Polyphemus loves Galatea, and wants her to love him in return. At the next narrative level, however, the situation changes radically. In Idyll 11, the narrator at this level is "Theocritus," who represents the author of the poem. His sphere is therefore poetry; but he makes the ambitious claim that poetry can act as a remedy ( $\phi \alpha \dot{\varrho} \mu \alpha x o v 1$ ) against lovesickness. His narratee is Nicias, a doctor (iat@óv 5), and thus someone who knows about remedies in general; but he is also interested in literature

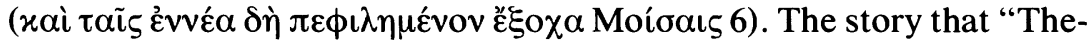
ocritus" tells Nicias is significant for both of them in that it unites their diverse interests: Polyphemus, like "Theocritus" the poet, gives himself over to song, and in the process, like Nicias the doctor, is said to cure himself of a painful affliction. ${ }^{66}$ Contrast this situation with that of Metamorphoses 13: Galatea, a beautiful nymph courted against her will by Polyphemus, tells the story of his unsuccessful courtship to Scylla, who resembles her in many respects. Scylla herself is introduced to the reader as an evidently beautiful maiden (virgo 734) whom many suitors courted (hanc multi petiere proci 735), but who rejected all of them (quibus ... repulsis 735) and then went to the seashore, where she told her friends the nymphs (736) stories about these young men's disappointed loves (elusos iuvenum narrabat amores 737). This general situation is then particularized: as Scylla combs the hair of one of these nymphs, Galatea, the latter responds to her story or stories with the tale of her love for Acis and the unwelcome courtship of Polyphemus. Here too, then, as in Idyll 11, the story of Polyphemus' courtship unites narrator and narratee; but the union is made on very different terms. Rather than expressing a happy unity between poet and physician in the power of song to cure lovesickness, in Ovid the story unites two attractive women, both of them accomplished storytellers, in their disdain for unwelcome courtship.

${ }^{66}$ Said, that is, by "Theocritus" the narrator, and most critics have agreed. But A. S. F. Gow, Theocritus ${ }^{2}$ (Cambridge 1952) 211 ad 11.13 worries that Polyphemus' song is both a symptom of and a cure for lovesickness, and notes that "the whole content of the song ... shows Polyphemus very far from cured." More recently Simon Goldhill, "Framing and Polyphony: Readings in Hellenistic Poetry," PCPS 32 (1986) 25-52, follows Gow in tracing this paradox to ambiguous language in the narrative frame, finding in the crisis of authority provoked by disagreement between the narrative voice and that of Polyphemus a characteristic feature of Hellenistic poetry. 
The symmetry between the respective situations of Scylla and Galatea is not, however, perfect. Scylla is represented as reluctant in general, without explanation. ${ }^{67}$ The vain efforts of her would-be lovers provide the material for her stories. Galatea's response to her stories is that Scylla is fortunate in that at least no savages woo her and that she can reject those that do court her without fear of reprisal (740-41). In Galatea's case, despite her divine parentage (742-43), it proved impossible to reject the attentions of Polyphemus without paying the price of mourning the man she did in fact love (744-45). The story that follows thus contains a much more chilling message for Scylla than "Theocritus'" story holds for Nicias: that within the suitor's courtship lurks the threat of violence and grief, which rejection may elicit. ${ }^{68}$

This striking reversal of Theocritus corroborates our earlier point about the resolution of tensions within Idyll 11 as compared with an emphasis on difference in the Metamorphoses. Galatea's rendition of Polyphemus' lovesong clearly problematizes the monster's appearance in a pastoral setting. She thus shows herself a very different narrator from "Theocritus" in Idyll 11, who pretends to regard Polyphemus-a Sicilian, after all, like "Theocritus" himself, and a shepherd, like the characters of several other idylls - as quite at home in a pastoral poem. This shift in emphasis, which keeps the polyphonic nature of the passage constantly before the reader's mind, is obviously reflected in the allusive artistry of the serenade itself. But it depends in large measure on the fact that Ovid tells us this entire story in the words of an interested party, the object of Polyphemus' uncouth desire, a woman who was forced to look helplessly on as this monster murdered her lover. It is no surprise, then, that she narrates the episode in such a way as to present the Cyclops as a paradox, whether we view him in pastoral, elegiac, or epic terms, being a creature who lives the shepherd's life and feels erotic yearning, but who cannot escape the violent tendencies of his epic background.

In the light of these ambivalences, the generic character of the episode may be called into question. It will by now be immediately apparent that it answers, at least in part, to the functional requirements of several genres. By narrating the story, Galatea plays the role of Theocritus, the pastoral poet par excellence. This much is obvious from the

${ }^{67} \mathrm{Cf}$. Polyphemus' wish that Galatea would reject all suitors (Met. 13.859-61).

${ }^{68}$ On the relationship between these paired stories see Betty Rose Nagle, "A Trio of Love-Triangles in Ovid's Metamorphoses," Arethusa 21 (1988) 75-98. 
fact that the kernel of the episode, which she herself relates, takes as its formal model Theocritus' eleventh Idyll, and that her role as narrator, rather than that of "Ovid," is modeled on that of "Theocritus" in that poem. But the story that she tells ends with Polyphemus' slaying of the "hero" Acis in single combat; and its many references to the Polyphemus of Homer and Vergil corroborate the impression that we are dealing with epic narrative. Finally, her story is elegiac, in three senses. First, it is a love story. This is an important feature of the Theocritean prototype as well; but in Ovid, what had been the mime of Polyphemus' soliloquy has been assimilated to the form of erotic narrative. Second, Galatea's narrative can easily be read as a lament for Acis, and thus as

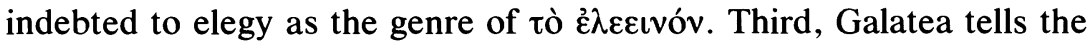
story to Scylla with an implied didactic intent, the relevance of which is borne out by the tragic events of the ensuing tale of Scylla, Glaucus, and Circe. This intent alludes to that uniquely Ovidian species of elegy, erotodidaxis. But of course the episode is not an entirely satisfactory specimen of any of these genres. Finally, it is something very different from any of them, because in different ways it so tantalizingly alludes to each. This, I submit, is its essence: to draw upon a variety of constituent genres while belonging not to any of them, but rather to quite a different genre defined only by its ability to subsume these other forms.

We may conclude by asking how this conception of genre might contribute to a broader interpretation of the Metamorphoses. What do we gain by thinking of the poem as a product of dialogue or polyphony rather than in other terms?

The advantage of this model lies in its applicability to issues beyond that of genre. We have seen one example of the polyphonic nature of Ovidian narrative in the nested structure of the Polyphemus episode. The idea applies equally well to the voice of the authorial narrator throughout the poem, a voice that persistently undermines itself, problematizing its own authority-a voice, that is, in dialogue with itself. The same is true of the poem's widely varying themes. In the broadest terms, the Metamorphoses is concerned with the normally discrete languages of philosophy, myth, history, and, for want of a better word, "daily life." Ovid does not attempt to unify these distinct modes of discourse, other than by using all of them as the ingredients of his carmen perpetuum. More frequently, he exploits their incongruity to achieve effects that range from humorous to disturbing, often managing (as in this episode) to be both at the same time. 
Ultimately, we must relate this, the defining feature of the poem, to the cultural milieu that engendered it and on which it comments. ${ }^{69} \mathrm{To}$ do so is obviously outside the scope of this paper; but it seems apposite to observe that one of the most notable features of the Metamorphoses is its recurrence to contrasts between a pluralistic, anti-authoritarian stance and an aggressive, domineering, and, as it were, monologic force. This type of confrontation, which is about the fragility of dialogue in the presence of a unifying, assimilating will, clearly stands at the center of the poem's meaning. It was also, as Ovid's personal experience tragically attests, a crucial issue in the increasingly authoritarian climate of the late Augustan principate. In this respect, the tale of Acis, Galatea, and Polyphemus is utterly typical of the Metamorphoses. The Cyclops, unable to accept the untidy realities of a world that does not conform to his desire, destroys what he cannot abide, turning love into grief. Thus the model of dialogism addresses not only the episode's generic character, but relates directly to its thematic structure at the deepest level, with obvious parallels in both cases to Ovid's poem as a whole.

University of Pennsylvania

JOSEPH FARRELL

${ }^{69}$ For farther-reaching cultural applications of dialogism in Bakhtin's work see Susan Stewart, "Shouts in the Street: Bakhtin's Anti-Linguistics," Critical Inquiry 10 (1983) 265-81 (repr. in Bakhtin: Essays and Dialogues on his Work, ed. Gary Saul Morson [Chicago and London 1986] 41-57), and Todorov (note 13 above) 97-112. For parallel developments in post-Heideggerian hermeneutics, see (e.g.) Hans-Georg Gadamer, Truth and Method, ${ }^{2}$ tr. and rev. Joel Weinsheimer and Donald G. Marshall (New York 1990); Dominick LaCapra, Rethinking Intellectual History: Texts, Contexts, Language (Ithaca 1983). 